\title{
PENGARUH PENAMBAHAN SUMBER PROTEIN NABATI BUNGKIL KELAPA TERHADAP PERTAMBAHAN BOBOT BADAN TERNAK KAMBING PERANAKAN ETTAWA (PE)
}

\author{
Hariyati Sarimo, Nibras K. Laya², Umbang A Rokhayati² \\ 1. Alumni of Animal Husbandry department, Faculty of Agriculture, Gorontalo State University \\ 2. Animal Husbandry department, Faculty of Agriculture, Gorontalo State University \\ Email:hariyatisatrimo@gmail.com
}

\begin{abstract}
The study aimed to determine body weight gain and feed conversion. This research was conducted in March 2019 April 2019. The location of the study was conducted in Paris Village, Mootilango District, Gorontalo Regency. The study used 20 female ettawa (PE) Peranakan goats with age 2-3 years by providing forage feed and $50 \%$ coconut cake added. While processing data using the $t$ test. The results showed that the addition of coconut cake was significantly different $(\mathrm{P}>0.05)$ to the value of the weight gain of ettawa goat breeds. where the average increase in body weight of ettawa Peranakan goat (PE) is $33 \mathrm{~g} /$ head / day. For feed conversion in ettawa (PE) crossbreed goats who were given an additional feed of coconut cake showed feed conversion of $0.18 \%$ and Etawa Peranakan goats given forage feed alone had a feed conversion value of $0.27 \%$. The conclusion is that the addition of coconut cake was significantly different $(\mathrm{P}>0.05)$ on the increase in Ettawa $(\mathrm{PE})$ goat body weight gain.
\end{abstract}

Keywords: Ettawa (PE) breed, forage, coconut meal

\section{PENDAHULUAN}

Kambing merupakan ternak ruminansia kecil yang memiliki nilai ekonomis cukup tinggi terutama dalam penyediaan sumber protein hewani dibandingkan dengan jenis ternak ruminansia lainnya. Hal ini disebabkan karena kambing cepat berkembang biak, jumlah anak per kelahiran lebih dari satu ekor, dan jarak antara kelahiran pendek. Selain itu, kambing memiliki adaptasi yang tinggi seperti mampu bertahan hidup di lingkungan buruk dengan memanfaatkan pakan (terutama hijauan) yang rendah kandungan gizinya. Namun pengembangan kambing Peranakan Ettawa (PE) dinilai masih rendah, dikarenakan sistem pemeliharaannya masih sebagai usaha sambilan dengan jumlah yang bervariasi. kambing Peranakan ettawa (PE) merupakan salah satu plasma nutfah ternak kambing Indonesia yang jumlah populasinya belum diketahui secara pasti. Dilihat sari daerah penyebarannya yang tidak begitu luas mengindikasikan populasi ternak ini tidak terlalu banyak dibandingkan dengan kambing kacang yang hampir tersebar di seluruh nusantaranya.

Pakan merupakan komponen utama di dalam ekonomi usaha, karena diperkirakan dapat menyumbang biaya 50$60 \%$ dari total biaya produksi (Devendra dan Sevilla, 2002). Pakan merupakan faktor terbesar yang mempengaruhi produktivitas ternak. Kondisi pakan (kualitas dan kuantitas) yang tidak mencukupi kebutuhan, menyebabkan produktivitas ternak menjadi rendah, antara lain ditunjukkan oleh laju pertumbuhan yang lambat dan bobot badan rendah. Menurut Treacher (2006) kambing pada masa pertumbuhan membutuhkan nutrisi yang lebih banyak dibandingkan dengan kambing yang sedang tidak berproduksi. Meskipun ternak memiliki potensi genetik yang tinggi, namun tanpa dukungan pemberian pakan yang tepat, maka produksi ternak tersebut tidak dapat 
optimal. Lahan pertanian yang semakin sempit menyebabkan ketersediaan hijauan yang masih berkurang, baik dari segi kualitas maupun kuantitas, sehingga solusi untuk mengatasi permasalahan tersebut dengan mengimbangi nutrisi ternak melalui penambahan konsentrat dalam bentuk ransum komplit. Salah satu upaya peningkatan produktivitas ini dengan memanfaatkan bungkil kelapa sebagai pakan ternak sumber protein. Di karenakan masyarakat di Desa Paris Kec. Mootilango Kab. Gorontalo belum mengetahui bahwa bungkil kelapa dapat di jadikan pakan ternak. Hal ini yang melatar belakangi penulis mengambil judul pertambahan bobot badan kambing Peranakan Ettawa dengan memberikan pakan tambahan bungkil kelapa dan menegetahui berapa pertambahan bobot badan yang diperoleh kambing Peranakan ettawa dari penambahan bungkil kelapa.

\section{METODE PENELITIAN}

Penelitian telah dilaksanakan pada bulan Maret 2019 - April 2019, bertempat di Desa Paris Kecamatan Mootilango, Kabupaten Gorontalo. Jumlah ternak yang digunakan dalam penelitian ini berjumlah 20 ekor dengan rataan umur berkisar antara 2-3 tahun dan memiliki bobot badan 30-40 kg. Dimana 10 ekor diberikan pakan hijauan saja (kangkung, rumput gajah, dan gamal) sedangkan 10 ekor lainnya diberikan pakan hijauan (kangkung, rumput gajah, dan gamal) dan ditambahkan dedak padi $2 \%$ dari bobot badan/ekor yang di campur dengan bungkil kelapa sebanyak 50 gram/ekor.

\section{HASIL DAN PEMBAHASAN konsumsi pakan}

Banyaknya jumlah pakan yang dikonsumsi oleh seekor ternak merupakan salah satu faktor penting yang secara langsung mempengaruhi produktivitas ternak seperti pertambahan bobot badan.
Hal ini sangat terkait dengan nutrisi yang terkandung dalam pakan dan tingkat kecernaan pakan tersebut. Ransum yang memiliki nilai nutrisi tinggi dan tingkat palatabilitas yang baik dapat dengan cepat meningkatkan pertambahan bobot badan ternak selama penggemukan. Konsumsi pakan kambing peranakan Ettawa (PE) gambar berikut.

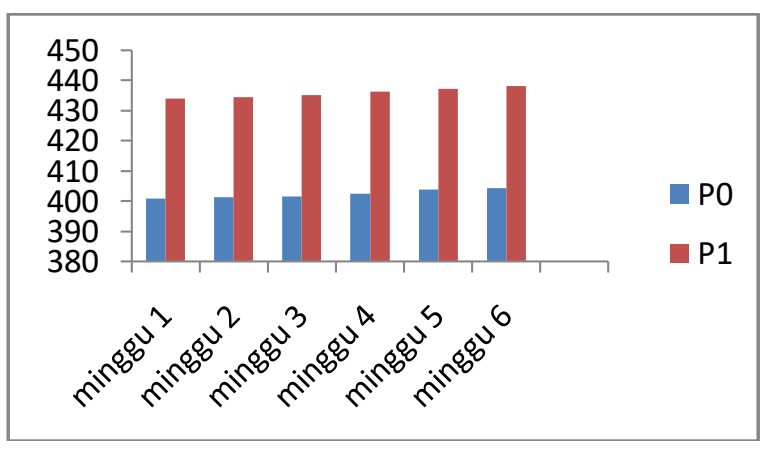

Gambar 1. Konsumsi pakan kambing Peranakan Ettawa (PE) yang diberikan pakan hijauan dan kosentrat yg ditambah bungkil kelapa bungkil kelapa.

Dari gambar 1 menunjukan bahwa perlakuan P1, konsumsi pakannya mempunyai rataan tertinggi dibandingkan dengan perlakuan P0. Tingginya konsumsi pakan pada perlakuan P1 diiringi dengan meningkatnya bobot badan ternak. Kartadisastra (1997), menyatakan bahwa bobot tubuh ternak senantiasa berbanding lurus dengan konsumsi ransum, makin tinggi bobot tubuhnya, makin tinggi pula tingkat konsumsinya terhadap ransum. Selain itu, konsumsi pakan yang maksimum sangat tergantung pada keseimbangan nutrien dalam pencernaan.

Pertambahan Bobot Badan

Pertambahan bobot badan ternak kambing Peranakan Ettawa (PE) diperoleh dari hasil penimbangan bobot badan akhir dikurangi bobot badan awal dan dibagi dengan selang waktu penimbangan. Pertambahan bobot dapat dilihat pada gambar 2. 


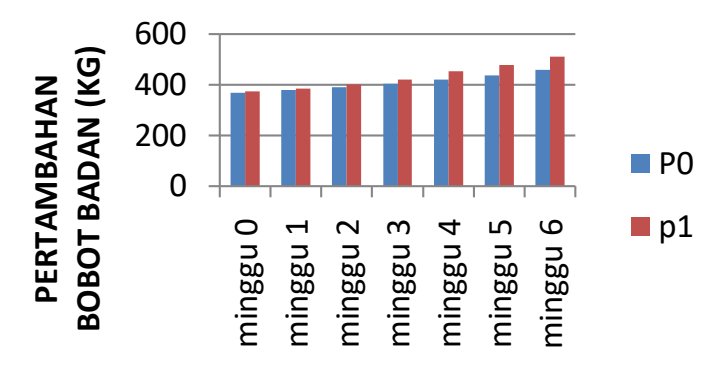

Gambar 2. Pertambahan bobot badan kambing Peranakan Ettawa (PE) yang diberikan pakan hijauan dan kosentrat yg ditambah bungkil kelapa.

Hasi uji $\mathrm{t}$ menunjukkan bahwa, pemberian kosentrat yang ditambah bungkil kelapa pada pakan kambing Peranakan Ettawa berbeda nyata $(P>0,05)$ dibandingkan dengan kambing yang hanya di berikan pakan hijauan saja. Pertambahan bobot badan tertinggi pada perlakuan P1 dengan PBBH 33 g/ekor/hari (2.5 kg/ekor/minggu). Hasi penelitian ini lebih tinggi dibandingkan dengan penelitian yang dilakukan Herlina Alim (2014) pada kambing merica 22,52 g/ekor/hari dengan memberikan pakan hijauan (rumput gajah) sebanyak 3\% dan di tambahkan pakan komplit sebanyak 10\%, kemudian perlakuan P0 PBBH 21 $\mathrm{g} /$ ekor/hari(1.5 kg/ekor/ minggu). Hasil penelitian ini lebih rendah dari pada yang diperoleh F.F. Munier dkk (2006) pada kambing peranakan ettawa betina 46.55 g/ekor/hari dengan memberika pakan hijauan berupa gamal sebanyak 500 g/ekor/hari sebelum digembalakan.

Pertambahan bobot badan kambing Peranakan Ettawa selama penelitian dengan perlakuan P0 rataan pertambanan bobot badan 21 g/ekor/ hari sedangkan perlakuan P1 rataan pertambahan bobot badannya $33 \mathrm{~g} /$ ekor/hari Hal ini sesuai dengan pernyataan Nursasih (2005). Pertambahan bobot badan ternak ruminansia sangat dipengaruhi oleh kualitas dan kuantitas pakan, hal ini yang dimaksud adalah penilaian pertambahan bobot badan ternak sebanding dengan ransum yang dikonsumsi.

\section{Konversi pakan}

Konversi pakan adalah salah satu cara untuk mengetahui seberapa besar kebutuhan pakan yang harus dikonsumsi untuk menaikan satu kilogram daging atau PBBH. Rataan konversi pakan pada kambing Peranakan Ettawa (PE) dengan pemberian pakan hijauan dan kosentrat yg ditambah bungkil kelapa selama penelitian dapat dilihat pada gamber berikut.

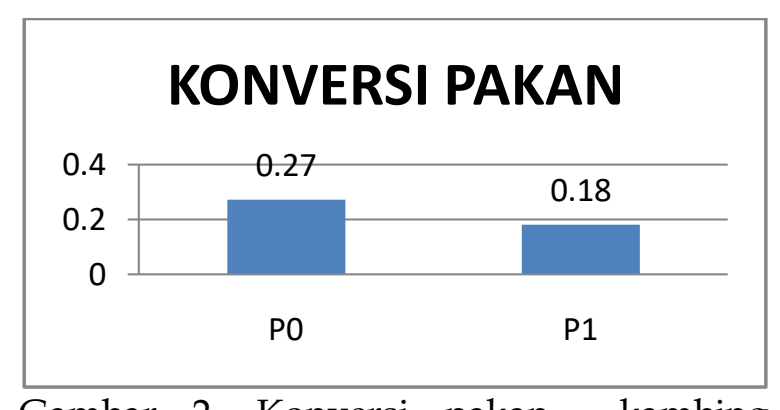

Gambar 2. Konversi pakan kambing Peranakan Ettawa (PE) yang diberikan pakan hijauan dan kosentrat yg ditambah bungkil kelapa.

Berdasarkan gambar 2 , dapat dilihat bahwa konversi pakan ternak kambing Peranakan Ettawa (PE) yang diberikan hijauan saja lebih rendah dibandingkan dengan ternak kambing perakan Ettawa yang di berikan kosentrat yg ditambah bungkil kelapa. Gambar 3. menunjukkan bahwa perlakuan P0 dengan rataan nilai konversi pakan tertinggi sebesar 0.27 gram memiliki pertambahan bobot badan (21 g/hari) sedangkan p1 dengan nilai rataan konveksi pakan terendah sebesar 0.18 gram memiliki pertambahan bobot badan (33g/hari). Konversi pakan pada penelitian ini lebih rendah dari NRC (2006) yang menyatakan bahwa konversi pakan yang disarankan 3.00 artinya pakan yang digunakan dalam penelitian ini sudah efisien dalam penggunaan pakan untuk dirubah menjadi daging. Penambahan bungkil kelapa 
memberikan nilai konversi yang kecil dan diikuti oleh pertambahan bobot badan harian kambing Peranakan Ettawa.

Hal ini sesuai dengan pendapat Juarini dkk. (1995) yang menyatakan bahwa konversi pakan pada ternak ruminansia dipengaruhi oleh kualitas pakan, besarnya pertambahan bobot badan, dan nilai kecernaan sehingga dengan pemberian kualitas pakan yang baik akan mendukung ternak untuk memiliki pertumbuhan yang lebih cepat. Selain itu hal ini juga didukung oleh pendapat Martawidjaya dkk. (1999) yang menyatakan bahwa konversi pakan khususnya pada ternak ruminansia dipengaruhi oleh kualitas pakan, pertambahan bobot badan dan nilai kecernaan.

\section{KESIMPULAN}

Berdasarkan hasil penelitian maka dapat disimpulkan bahwa pemberian pakan tambahan bungkil kelapa lebih baik memberikan pertambahan bobot badan kambing Peranakan Ettawa, atau lebih disukai dibandingkan dengan pakan hijauan tampa diberikan penambahan bungkil kelapa. Rata pertambahan $\mathrm{PBBH}$ kambing peranakan ettawa yang diberikan pakan tambahan bungkil kelapa sebesar 33g/ekor/hari. Konversi pakan pada kambing Ettawa yang diberikan pakan tambahan bungkil kelapa lebih rendah dibandingkan yang di berikan pakan hijauan saja.

\section{DAFTAR PUSTAKA}

Devendra, C. and C.C. Sevilla. 2002. Availability and use of feed resources in crop animal systems in Asia. Agric. System 71: 59 - 73.

F.F.Munier.2006. Pertambahan bobot badan harian kambing peranakan ettawa (PE) betina yang diberikan pakan tambahan hamal (Gliricidia sepium).
Balai pengkajian teknologo pertanian Sulawesi tenggah. Bogor

Herlina Alim. 2014. Pertambahan Bobot Badan Kambing Marica Jantan Dengan Pemberian Pakan Komplit Pada Taraf Protein Yang Berbeda. Skripsi. Fakultas Peternakan. Hassanudin Makassar

Juarini, E. I. I. Hasan, B. Wibowo, dan A. Tahar. 1995. Penggunaan konsentrat komersial dalam ransum domba di pedesaan dengan agroekosistem campuran (sawah tegalan) di Jawa Barat. Pros. Seminar Nasional Sains dan Teknologi Peternakan. Balai Penelitian Ternak. Bogor. hal. 176181.

Kartadisastra, H. R. 1997. Penyediaan dan Pengelolaan Pakan Ternak Ruminansia. Kanisius, Yogyakarta.

Martawidjaja, M, B. Setiadi, S.S. Sitorus. 1999. Pengaruh tingkat proteinenergi ransum terhadap kinerja produksi kambing kacang muda. Jurnal Ilmu Ternak dan Veteriner. 4.(3). 167-172.

National Research Council. 2006. Nutrient Requirements of Small Ruminants (Sheep, Goats, Cervids, and New World Camelids). National Academic Press. Washington, D.C.

Nursasih, E. 2005. Kecernaan zat makanan dan efisiensi pakan pada kambing Peranakan Etawah yang mendapat ransum dengan sumber serat berbeda. Skripsi. Fakultas Peternakan. Institut Pertanian Bogor. Bogor. 